\title{
FIRST-CONTACT ACCESSIBILITY ATTRIBUTE IN PRIMARY HEALTH CARE SERVICES AND CARE PRACTICES: CONTRIBUTIONS TO ACADEMIC EDUCATION FOR NURSES
}

\author{
Gabriela Fávero Alberti' ${ }^{1}$ Maria Denise Schimith², Maria de Lourdes Denardin Budó ${ }^{3}$,Gabriela Leal Neves ${ }^{4}$, Laís \\ Fuzer Rosso ${ }^{5}$
}

\begin{abstract}
${ }^{1}$ M.Sc. in Nursing. Programa de Pós-Graduação em Enfermagem, Universidade Federal de Santa Maria (UFSM). Santa Maria, Rio Grande do Sul, Brazil. E-mail: g_falberti@hotmail.com

${ }^{2}$ Ph.D. in Sciences. Professor, Programa de Pós-Graduação em Enfermagem, UFSM. Santa Maria, Rio Grande do Sul, Brazil. E-mail: ma.denise2011@gmail.com

${ }^{3}$ Ph.D. in Nursing. Professor, Departamento de Enfermagem, UFSM. Santa Maria, Rio Grande do Sul, Brazil. E-mail: lourdesdenardin@ gmail.com

${ }^{4}$ Nursing Undergraduate, UFSM. Santa Maria, Rio Grande do Sul, Brazil. E-mail: gabi_leal_neves@hotmail.com

${ }^{5}$ Nurse, UFSM. Santa Maria, Rio Grande do Sul, Brazil. E-mail: laisfrosso@gmail.com
\end{abstract}

ABSTRACT: Case study that aimed to identify the care practices of nurses from a Family Health Unit related to the first-contact accessibility attribute and the contributions to academic nursing education. The data is an excerpt from a database, collected from February to July 2012. Semi-structured interviews were conducted with nurses, participant observation of the care practices took place and a document search was undertaken, analyzed according to the operation proposal. The first contact can be initiated by the demand of the user himself or staff meetings based on the cases shared by the community health agents. The nurses' behavior restricts user access and excludes the possibility of welcoming. Academic training should insert and integrate the students into different scenarios and knowledge; foster human understanding based on the opening to new sensibilities and unpredictability, besides instigating the authentic participation of the student in his learning process.

DESCRIPTORS: Nursing. Nursing care. Primary health care. Family health strategy. Education.

\section{ATRIBUTO DO PRIMEIRO CONTATO NA ATENÇÃO BÁSICA E PRÁTICAS DE CUIDADO: CONTRIBUIÇÕES PARA A FORMAÇÃO ACADÊMICA DO ENFERMEIRO}

RESUMO: Estudo de caso que objetivou conhecer as práticas de cuidado de enfermeiros de uma Unidade de Saúde da Família relacionadas ao atributo do primeiro contato e as contribuições para a formação acadêmica. Os dados são um recorte de um banco de dados, coletado de fevereiro a julho de 2012. Foram realizadas entrevistas semiestruturadas com enfermeiros, observação participante das práticas de cuidado e busca documental, analisados conforme proposta operativa. O primeiro contato pode ser iniciado pela demanda do próprio usuário ou em reuniões de equipe a partir dos casos compartilhados pelos agentes comunitários de saúde. As condutas dos enfermeiros restringem o acesso do usuário e excluem a possibilidade de acolhimento. A formação acadêmica deve inserir e integrar o graduando a os diferentes cenários e saberes; incentivar a compreensão humana a partir da abertura para novas sensibilidades e a imprevisibilidade, além de instigar a participação autêntica do graduando em seu processo formativo.

DESCRITORES: Enfermagem. Cuidados de enfermagem. Atenção primária à saúde. Estratégia saúde da família. Educação em enfermagem.

\section{ATRIBUTO DEL PRIMERO CONTACTO EN LA ATENCIÓN BÁSICA Y PRÁCTICAS DE CUIDADO: CONTRIBUCIONES PARA LA FORMACIÓN ACADÉMICA DEL ENFERMERO}

RESUMEN: Estudio de caso con objetivo de identificar las prácticas de cuidado de enfermeros de una Unidad de Salud de la Familia relacionadas con el primer contacto y atribuir contribuciones a la formación académica. Los datos son un recorte de una base de datos, recogidos de febrero a julio de 2012. Fueron realizadas entrevistas semiestructuradas con los enfermeros, la observación participante de las prácticas de atención y búsqueda de documentos y analizado conforme propuesta operativa. El primero contacto puede ser empezado por el propio usuario o cuando los agentes comunitarios de la salud comparten sus casos en las reuniones de equipo. Las conductas de los enfermeros restringen el acceso del usuario y excluyen la posibilidad de la acogida. La formación académica debe introducir e integrar graduar a diferentes escenarios y conocimientos; la comprensión humana de acogida de la apertura a nuevas sensibilidades y la imprevisibilidad, así como instigar la participación auténtica de la estudiante en su proceso de aprendizaje.

DESCRIPTORES: Enfermería. Atención de enfermería. Atención primaria de salud. Estrategia de salud familiar. Educación en enfermería. 


\section{INTRODUCTION}

The initiatives of the Brazilian Unified Health System (SUS) culminate in changes in the political, social and economic context, in which Primary Health Care (PHC) and the Family Health Strategy (FHU) are the main elements affecting the paradigm change in the current health care model. These represent the primary access level, in which health care is based on social practices, at an interface, beyond the technical and professional dimension, as it includes the reorganization of the system, such as care coordination in the Health Care Network $(\mathrm{HCN})$, according to the logic of guaranteeing the continuity, problem solving ability and community participation in care. ${ }^{1-3}$

One of the challenges to put the SUS in practice is professional education coherent with this complex work field. The daily reality of the health services is a constituent element of the education process, as it implies the development of new health practices, stimulating the subjects' implication. ${ }^{4}$

The National Curricular Guidelines (NCG) guide the type of curriculum and education the students should receive and, thus, they also regulate the conducts of the subjects involved in the education process. More than ten years after the implementation of the NCG in the nursing courses, the guidelines are currently being reformulated, as the changes in academic education are still incipient and insufficient.

This reveals the need to reflect on the implication of health professionals' education process, with a view to starting a dialogue that contributes to the education spaces in the learning/teaching/ constructing of care practices. The reflection should consider the premise that the care habitus is developed and/or acquired in education and then runs through the professional space.

To guarantee high-quality PHC, its attributes need to be put in practice as a whole: the core attributes, considered as first-contact accessibility, continuity, comprehensiveness and care coordination. ${ }^{2}$ For the discussion proposed in this article, the first-contact accessibility attribute was used as the guiding axis to analyze the results, as it implies the accessibility and the user's access to the health service. The primary premise is that the constitution of the user's flow in the HCN starts with the reception at the Family Health Unit (FHU), characterized as the user's first contact with the health service. Theoretically, during this encounter, the users present their health needs that triggered the search for the service.
Therefore, the question is raised how the nurses' care practices at a FHU contribute to reflect on the academic education related to the firstcontact accessibility in PHC?. And the following objective is established: getting to know the nurses' care practices at a FHU related to the first-contact accessibility attribute and its contributions to academic education.

\section{METHOD}

The research method used was the case study, as it "emerges from the desire to understand complex social phenomena" 5:24 and allows the researcher to capture the holistic and significant characteristics present in real contexts. An excerpt was used from the database belonging to the matrix research entitled "Relations between health workers and users at a family health service: the construction of the health care network".

The analysis unit studied was a FHU of a city in the central region of the State of Rio Grande do Sul. The FHU has two primary health care teams and one oral health team, which divide the same facilities. The data were collected from multiple sources of evidence, an important component that characterizes the case study. The data collection techniques that composed the excerpt from the database studied were semistructured interviews with nurses, participant observation, including field diary registers about the care practices, besides searches in documents and information system records (proceedings from team meetings, reports from the Primary Care Information System (SIAB), forwarding agenda). Documentary analysis was used with caution, specifically to support the in-depth understanding of the case studies, corresponding to the exploratory phase of the data analysis, described below.

The analysis and interpretation of the data were guided by the operation proposal, whose author indicates two operational levels. The first is exploratory and aims to get to know the historical context of the object and for the researcher to get familiar with the database. The second is interpretive and subdivided in three phases, described next. The ranking of the data was based on the transcription, reading, rereading and organization of the reports in a certain order. It is valid to highlight that this phase was already constructed due to the database. ${ }^{6}$ Therefore, the collected material was organized in three printed polygraphs, each of which referred to the data collection technique used in chronological order, and also in a digital ver- 
sion of the interviews and the field diaries.

The classification, the second phase, comprised dense and exhaustive readings to apprehend the relevant structures, situations and key moments on the theme studied. As the PHC attributes constituted the background for the initial analysis of the data, in this phase, notes were organized on colored notepads, signaling the substrates that were considered relevant to respond to the research objective, specifically considering the attribute of first-contact accessibility. The final analysis, then, highlights the reversal of the two previous phases on the empirical material, which the author considers as a true dialectic movement. ${ }^{6}$ In that sense, the situations identified as the first contact were analyzed and discussed with the theoretical reference framework used.

The case studies cannot be generalized to the populations and universes. Thus, the resulting theorizations can be considered generalizations. ${ }^{5}$ In the methodological phase of the analysis and interpretation, the results were confronted with the social reality of the service under analysis, the FHU, so that the results unveiled "[...] focus on a strategic link with the reality" ${ }^{6: 237}$ In this article, the presentation of the results focused on the attribute of first-contact accessibility, and therefore clarifies the central category: health education for the first contact. The research received approval from the Research Ethics Committee at Universidade Federal de São Paulo, N. 1939/11. The ethical considerations were safeguarded through the signing of the form authorizing the use of the database, which discussed the authorization and use of these data for this research, conditioned to Resolution 466/2012 on research involving human beings.

\section{RESULTS}

To clarify the central category, the situations observed during the data collection are presented next. With regard to the predefined demands and the possibility to make an appointment with the nurses: researcher seeks information about the nurses' agenda: it is a single agenda for the two nurses. The cover says: cytopathology, childcare and prenatal care appointments can be made. Time: $9 \mathrm{~h}-11 \mathrm{~h}$ and $13 \mathrm{~h} 30 \mathrm{~min}$. till $15 \mathrm{~h}$. Thirty minutes per appointment. On the whole, nine hours are available for the two nurses. On some days, the agenda is not open, like when the SIAB is closed and team meetings are held (Field diary 05/02/2012, afternoon shift.

The predefined agenda suggests that the nurses concentrated their actions on women and children. The production of the data and the clos- ing of reports like the SIAB exclusively took place between the nurse and the community health agent (CHA), without involving other team members.

As regards the regular team meetings, most of the nurses were present, but took a passive posture, as they did not assume a leading position. The discussion points the team emphasized most referred to the service's facilities, the demands the $\mathrm{CHAs}$ presented and the transmission of information from the Municipal Health Department (MHD), like information from the immunization sector, tuberculosis ( $\mathrm{Tb}$ ) sector, as evidenced in the documents analyzed.

The following report describes a situation in which, although the nurse optimized the access to the existing medical appointment, the nursing appointment was not considered an option for the initial assessment: nurse at reception. A user arrives to vaccinate her daughter and comes to the reception and asks when the doctor is attending. The nurse answers: 'Today.' The user, surprised, asks: 'Today?' Nurse: 'Yes. And, by the way, there's still place.' User: 'How many people are there in front of me?' Nurse: 'Seven.' User: 'Then I want an appointment, schedule one for me.' Nurse: 'OK. Just wait to be called then' (Field diary 04/03/2012, afternoon shift).

Upon her first contact we the user, the nurse presupposed the possibility of welcoming the singularity that exists in each situation and simultaneously mobilized her technical-scientific knowledge to assess and consider the vulnerability that exists in each case. Nevertheless, this action of the nurse was not visible in the observation presented.

In the next situation, it is identified that one of the ways to start the first contact is through another professional, like the CHA: while typing in the SIAB, the CHA comments to the nurse that a baby is getting milk from bags and has got diarrhea. He's two months old, was born prematurely, stayed at the university hospital (UH) and did not want to breastfeed. The nurse asks: 'Diluted milk?' CHA: 'She boils it'. Nurse: 'You need to dilute it somewhat. Why doesn't he breastfeed?' CHA: 'He was born prematurely. He stayed at the UH and did not want to breastfeed'. CHA types the rest of the text (Field diary from 04/17/2012, afternoon shift).

In this dialogue, the CHA identified some characteristics of the situation as a potential risk and thus shared them with the nurse. The academic education should permit the encounter between nursing and other professions that participate in daily work, in order to start, while still in undergraduate education, dialogues that make it possible to know other areas. In addition, conducts of 
complementary knowledge should be developed to address attitudes of accountability and construction of singular and collective therapeutic projects, which also value the user's participation in this construction. This educational perspective helps to arouse skills for interdisciplinary action and teamwork in the nursing undergraduates.

On another occasion, the nurse's practice resulted in the restriction of the access and thus excluded the possibility to welcome the user's demand: nurse at reception. A mother arrives whose child was having a fever and vomiting since morning. Nurse says that the doctor sees no more than 15 files and that it was useless to insist. Nurse comments to the researcher that the mother is sloppy because she had all day to do something for the child to get better but only comes to the service now, 15h. Researcher suggests a nursing consultation or forwarding to the emergency care (EC). Without answering the suggestion, the nurse leaves the place (Field diary 04/19/2012, afternoon).

In this case, the nurse did not try to discover and contextualize the information to explain the visit to the health service at that time only. At the same time as other people's suffering is trivialized, the nurse adopted a disrespectful posture: she blamed the user and, as a form of punishment, denied attendance, without offering possible alternatives to intervene in the case, infringing on the ethical imperative of PHC that all demands should be welcomed. Academic education should invest in strategies that stimulate competency building, taking the form of attitudes of understanding the other, opening up to new sensitivities imbued in the ethical and human dimensions that cross the relationship sphere.

Concerning the management of team care, one nurse charged the CHAs in her attitude: team meeting: nurse says: 'This morning it happened again, it's not the first time. A child came with throat ache, it was there at the UH and they said it wasn't for the EC. She arrived here at 10h. and there were no more doctors'. She continues: 'You need to instruct the people not to go to the UH' (Field diary 05/02/2012, afternoon).

In view of the above, the contradiction is identified in PHC's function as first contact and preferred entry door into the health system, and that the user visits another emergency service as the primary alternative. The nurse's charging posture suggests that the user's rejection of the PHC service is because the CHAs' instructions are incoherent with the FHU proposal, ignoring other aspects influencing the user's choice.

In the three situations exposed above, the nurse puts herself in a condition of depending on the physician's presence at the service to deliver care to unexpected demands, which emerge daily. This condition of dependence infringes on her own professional autonomy as she does not acknowledge the nursing consultation as a technology represented as an autonomous nursing practice.

The latter two excerpts from the observations are similar because they are spontaneous demands that inevitably emerge in the daily service reality. Based on the conduction of each case, it can be inferred that there are no programmed activities to attend to the spontaneous demand at the service, another specific nursing task in PHC. On the other hand, procedures systematically offered at the FHU are also demanded, such as immunization: nurse at reception. User arrives with a baby for vaccination. The nurse, who is not doing anything at the moment, because it is $15 \mathrm{~h} 45 \mathrm{~min}$. and there is nobody at the FHU, says that vaccination is administered on Thursday mornings. The user says: 'I came the other day and it was already closed'. Nurse: 'We close at 16 h'. User: 'But there at (name of the service) there is a poster saying the opposite'. Nurse: 'I'll call there, right now'. She calls and talks to the secretary, who confirms what the mother had said. She explains the right times and asks to change the poster (Field diary 04/19/2012, Thursday afternoon).

The user came up against the regulatory discourse concerning the way the work processes are organized at the FHU. In addition, attendance was denied to the user because, although she visited the service on the weekday indicated, the shift when she went to the service was the opposite of the service reserved for a routine procedure (in this case immunization). Another excerpt from the observation that should be highlighted is the nurse's attitude of checking the legitimacy of the user's information with the other service. The nurse's attitudes do not guarantee equitable access to the health service as, even though the error in the information that induced the user to error was actually observed, there was no attempt to compensate for the loss.

In that sense, it is considered that the education process should intend to overcome the activity modes that stifle the professional or whose actions are reduced to prescriptive, regulatory and/or bureaucratic acts. Education should go beyond what is naturalized - internalized as a standard - and work on the variability and unpredictability that permeate the daily reality of the health services with the undergraduates, also to make them think about the established standards that often invalidate the right to care.

The nurses' care practices should guarantee the coherence with the logic of the network that 
organizes the flows and counterflows of people through the different care points. The function of PHC to coordinate the user's movement through the $\mathrm{HCN}$ is highlighted. In the interview with one of the nurses, the professional assumed the responsibility of seeking information on the user when he is at another point in the $\mathrm{HCN}$, despite acknowledging that she does not know the flow: we often have to seek, we have to try and find out. Then he (the user) did not come, we did not find out the answer. But it's no trouble for us to pick up the phone and try and find him too. I think it is our duty, because he is part of our area, so we have to take responsibility for that. [...] we are confronted with situations in which we do not know where to head to. So that is another difficulty. We cannot see straight, we don't know where to go. We don't know the flow.

The nurse revealed her awareness of her joint responsibility in actively contacting users who are absent to discover the outcome of the health/disease situations when they were conducted to other points in the HCN. In other words, she acknowledges the relation between the care coordination and the professional's responsibility. This aspect strengthens the strategic position PHC plays, as a center and communication in the HCN, and highlights the function of health care coordinator. Nevertheless, her lack of knowledge on the flows/counterflows in the HCN negatively influences these functions of PHC, also revealed that there is little or no articulation among the other services in the $\mathrm{HCN}$ (intersectoriality).

In addition, her discourse reveals the professional awareness that highlights her duty to "pursue", and thus take on a more proactive attitude, open to get to know what is established with the user under her responsibility. In that sense, the role of academic education is the ability to encourage the students' proactive attitude, making them take on their authentic participation in the act of knowing, withdrawing the teacher's role as the unique holder of knowledge and making the student assume a protagonist role, in a permanent search for knowledge, questioning/challenging the knowledge the university often offers as absolute and true.

\section{DISCUSSION}

It is known that education should be significant, that it should move beyond the classical sense of knowledge transmission and surpass technical and scientific knowledge. ${ }^{4,7-8}$ The care practices occur in the space of human relationships. Therefore, they require the relationship of contact with the other and bonding with other people. These spaces should be present, in their diverse existing formats, in daily nursing education. Life spaces, each with its own singular context and, like each subject in the world has his/her own qualities and characteristics, there are collective contexts, like the political, ecological, social, among others. Hence, the human being becomes a subject in contact with the other. Thus, the relation of each context mutually and with the others constitute the whole, the global. ${ }^{9}$

The contact with the plural contexts, people, professions encourages the nursing undergraduates to get to know and reflect on the complexity of how life develops, as it produces estrangement and comprehension to the extent that new existential possibilities, social organization and meanings are revealed. For academic education, this teachinglearning perspective represents the possibility the break with what supposedly determined the professional being: the technique, the manual aptitude, instrumental skills, scientific theories, biology.

These reflections are in line with the principle of uncertainty, in which the scientific knowledge is not the sole absolute producer of truths. Using Morin's thinking, ${ }^{9}$ the inquiries serve as oxygen for any knowledge proposal, and knowledge is the fundamental objective of education.

In that sense, the principle of uncertainty should run through the nurse's academic education as, based on questioning, estrangement, the implication provoked in the student, there is margin for reflection. The attitude of estrangement presupposes a certain distancing from reality, from established truths, not immediately accepting them as definitive without submitting them to verification first.

By challenging the ideas received thus far without further investigation, the student can get to know other existing evidence, disintegrating the conservatism and contributing to solve the questioner's pre-established viewpoint. ${ }^{9}$ The reflection can also be a self-reflection when the student questions himself and aims to understand and get to know his role in the world intended by the awareness.

The analysis of the nurse's care practices provokes other reflections. What are the fundamental strengths that order the concentration of the nurses' care practices on women and children for example? Is there a relationship of coherence between what the population on the care territory considers necessary for itself, both individually and as a group? Is the epidemiological profile taken into account in the planning of care? It is known that the base of nursing education lies in the public health policies. In other words, the professional "[...] is submitted to orders 
that imperatively define their forms of acting/ thinking in care delivery or clinical practice" ${ }^{10: 532}$ How can what is established as priority care be delivered then, but without turning it into a form of submission of the professional who organizes his work process merely to cope with what is charged in a public policy, instead of what the claimants need in the territory they live in?

Education, by offering the immersion into daily action in the workspace, allows the undergraduate to think, critically analyze and relate theory and practice to resignify the sense of their education and work. Hence, "the decoding is the analysis and consequent reconstitution of the situation experienced: reflex, reflection and opening of concrete possibilities of overcoming. [...] what used to be closure, little by little opens up, the consciousness starts to listen to the appeals that always summon it to go beyond its limits: criticism is given". 11:11 Learning becomes more important than reminding, memorizing, learning by heart, as it imprints true meanings experienced in the undergraduate.

Triggering teaching-learning processes based on the questioning of existing situations in the practical context, with the help of the bias of mutual feedback, also contributes for the student to achieve a reflexive mode of thinking. Nevertheless, in a study developed to identify teaching methods nursing professors use, it was unveiled that the teachers know little about the problematization method and mistakenly relate it only with the development of case studies and problem-based studies. ${ }^{12}$

Through the reflection on the possibilities that exist in a single situation, including unpredictable ones, imply understanding the complexity and, in turn, permit the transformation and invention of other (new) care practices, dissolving naturalized practices based on the biological bias. Routes are opened to construct professional autonomy.

For the undergraduate, as the existing situations and the range of possibilities can be contextualized, prediction, anticipation skills are developed, as well as autonomy to act with a view to guaranteeing planning in health, negotiating the types of resources and technologies available to produce health and prevent problems. It is also clear that one of the imperatives of academic education becomes the development of the aptitude to organize the knowledge, that is, to think, ${ }^{9}$ relating it with the information and giving it meaning in view of the context it refers to.

A certain authors refers to blinkers as "[...] all concepts and assertions about which we have not reflected, and which we accept as if they meant something simply because it seems that everybody understands them". ${ }^{13: 15}$ The author refers to the mistaken assertion that it is the rationality that distinguishes us from other living beings, devaluing the emotion. Emotions, differently from the understanding of feeling, are "[...] dynamic bodily provisions that define the different action domains we move in" ${ }^{13: 15}$ Thus, education (and its close relationship with the development of ethical and human postures) should be focused on the construction of knowledge with the mastery of emotion, as "[...] we do not realize that all rational systems have an emotional background". 13:15

In other words, education should grant space for the student to reflect and think differently from what is established, and this new thinking should mainly influence professional action, in which the prevailing emotions should be ethics, respect and responsibility. When considering the blinkers of the education process in this understanding the author presents, another reflection can be launched: what assertions and concept permeate nursing undergraduates' education and are affecting their professional life? In that sense, cognitive development and the creation of technical skills for professional practice cannot be accepted as the final and unique function of nursing education. Therefore, the education process needs to be devised under the bias of the inventive dimension, considering that, "[...] work and education can also be a field for the production of new possibilities, manufactured by apprentices-inventors". 4:19

The challenge of overcoming daily practice can be confronted, based on the paradigmatic nature, acknowledging that there are other interdependent elements that compose the care practices and working with them in education. Because it are the assertions and concepts addressed in academic education that integrate the primary care practices, inscribed in the subjects, which will guide their way of thinking and acting, constituting a professional habitus.

It is evidenced that the FHU was not the preferred option. The welcoming attitude favors the establishment of bonding between professional and user and plays a determinant role in the choice of the service. The authors acknowledge that plenty remains to be done in PHC to guarantee a welcoming practice, as it includes a range of cultural aspects, values, communication, expression and experiences. ${ }^{14}$ This assertion focuses on the author of complex thinking, when he says that "[...] the human being is revealed to us in his complexity: being, at the same time, completely biological and 
completely cultural" .9:40 Compassionate, welcoming and reverent attitudes are necessary during the different meetings between professionals and users, so as to impose a new way of producing care in the workspace, as "[...] when we change emotion, we change the action domain". 13:15

As regards the welcoming dimension in the PHC services, authors highlight that investments are needed in two aspects: attitudinal and organizational. About the second aspect, although the routine is overvalued, as highlighted earlier, the professionals do not adopt attitudes that assess the work process developed at the service and self-assess their practices. The indiscriminate posture towards the organization, the professional attitude and what is executed induces a false awareness that what is being done to the other seems to be sufficient and appropriate. ${ }^{15}$

The experience is significant when the sensitive aspect is instigated and, thus, the education should encourage reflection and self-knowledge in the undergraduates, self-discovery, unveiling their aptitudes, skills, potentials, limits and other aspects, based on the real contact with the work world. Again, the problematizing method is appropriate, as problematizing the reality presupposes unveiling characteristics, contradictions, extracting problems and proposing solutions, ${ }^{20}$ in which the undergraduate takes an autonomous position of constructing their own teaching and learning process and the teacher serves as a facilitator of this process.

The quality of education is not only limited to the ability to work, but mainly extends to the "[...] aspects related to the way of living one's life, ethics in the use of knowledge and innovations, enhancement of cultural and political education and rescue of human dignity" $8: 67$ Thus, the reflection that emerges is: that other knowledge is useful, and that academic education can explore, for the future nurse to perform socially relevant practices, to the extent of provoking transformations in professional work.

Education in the light of the reality of work allows the former to feed the latter through the construction of knowledge, and the latter, in turn, appoints the ways to achieve this knowledge. This relationship of feedback does not exclude the idea that the work world is at the same time a space for knowledge construction. But it also allows the undergraduate, in the future activity space, to feel part of it and construct a posture of responsibility, implication, sensitivity and as a pro-active agent, who interferes in the established care production modes.

Thus, to achieve care modes at the interface of teamwork, education needs to get ahead and incorporate spaces that provide for interdisciplinarity, encouraging teaching-learning processes based on groupality, cooperation and dialogue with other educations, for example. Interdisciplinarity is a work process whose action exposes the complexity of the reality to the extent that different disciplines, existences and knowledge interact (instead of adding up), in the elaboration of a global context that requires intervention, which refers to "exchange and cooperation, thus turning into something organic $^{\prime \prime},{ }^{16: 50}$ permitting the construction of sustainability ways of change in health care, based on values like ethics, equity and integrality.

\section{FINAL CONSIDERATIONS}

The care practices observed indicate that a strong trend remains in pragmatic academic education that overvalues the technical-scientific skills, know-how and cognitive aspects, leaving the relational skills and the development of civil awareness and social accountability to the background. In a general perspective, one may say that there are certain movements of change in the spaces under debate: health and education.

In order to achieve the consolidation of the SUS in the way it was devised, health education needs to be appropriate to the country's social and political context. To understand the condition as a subject who transforms a social reality, education needs to develop the skills of reflection, self-reflection and prominence in the undergraduate, so that, by provoking the student's identification with the premises of the country's health project - the SUS, the future health professional, willing to defend it, assuming a posture of implication and commitment, mainly to the continuity and advance of the Health Reform movement.

The SUS is fertile ground in which education and health meet, as it is the main professional education space. The university, in this open and diverse scenario with possibilities for invention, shares and produces its knowledge relevant to the health reality. The effects of this new educational bias include the transformation of care practices, as well as the education of new professionals with collective awareness, apt to face the complexity, daring to invent new and ethical-sensitive-political practices, whose health care model to be achieved is care.

\section{REFERENCES}

1. Mendes EV. O cuidado das condições crônicas na atenção primária à saúde: o imperativo da 
consolidação da estratégia da saúde da família. Biblioteca Virtual do Ministério da Saúde [internet]. 2012 [cited 2014 Nov 12]. Available from: http:// bvsms.saude.gov.br/bvs/publicacoes/cuidado_ condicoes_atencao_primaria_saude.pdf

2. Starfield B. Atenção Primária: equilíbrio entre necessidades de saúde, serviços e tecnologia. Biblioteca Virtual do Ministério da Saúde [internet]. 2002 [cited 2014 Nov 12]. Available from: http://bvsms.saude. gov.br/bvs/publicacoes/atencao_primaria_p1.pdf

3. Barreto IS, Krempel MC, Humerez DC. O COFEN e a Enfermagem da América Latina Enfermagem em Foco [internet]. 2011 [cited 2014 Nov 12]; 2(4). Available from: http://revista.portalcofen.gov.br/index.php/ enfermagem/article/viewFile/195/131

4. Heckert AL, Neves CAB. Modos de formar e modos de intervir: quando a formação se faz potência de produção de coletivo. In: Ministério da Saúde (BR). Secretaria de Atenção à Saúde. Política Nacional de Humanização. Formação e intervenção. Brasília (DF): MS; 2010.

5. Yin RB. Estudo de caso: planejamento e métodos. $4^{a}$ ed. Porto Alegre (RS): Bookman; 2010.

6. Minayo MCS. O desafio do conhecimento: pesquisa qualitativa em saúde. $7^{\mathrm{a}}$ ed. São Paulo (SP): Hucitec; 2010.

7. Ceccim, RB. Feuerwerker, LMC. O quadrilátero da formação para área da saúde: ensino, gestão, atenção e controle social. Physis: Rev Saúde Coletiva [internet]. 2004 [cited 2014 Nov 12]; 14(1):. Available from: http://www.lume.ufrgs.br/ handle $/ 10183 / 27642$ ?locale=pt_BR

8. Grillo MJC, Silva KL, Sena RR, Tavares TS. A formação do enfermeiro e a necessidade de consolidação do sistema nacional de saúde. REAS [internet]. 2013 [cited
2013 Oct 15]; 2(2):. Available from: http:/ / www.uftm. edu.br/revistaeletronica/index.php/enfer/article/ view/402/408

9. Morin E. Os sete saberes necessários à educação do futuro. $2^{\mathrm{a}}$ ed. São Paulo (SP): Cortez; 2011.

10. Ceccim RB, Merhy EE. Um agir micropolítico e pedagógico intenso: a humanização entre laços e perspectivas. Interface (Botucatu) [internet]. 2009 [cited 2014 Oct 28]; 13(1):. Available from: http:// www.scielo.br/pdf/icse/v13s1/a06v13s1.pdf

11. Freire P. Pedagogia do oprimido. $57^{\mathrm{a}}$ ed. Rio de Janeio (RJ): Paz e Terra: 2014.

12. Paim AS. Iappe NT. Rocha DLB. Metodologias de ensino utilizadas por docentes do curso de enfermagem: enfoque na metodologia problematizadora. Enfermería Global [internet]. 2015 [cited 2015 Apr 23]; 37:153-69 . Available from: http://revistas.um.es/eglobal/ article/view/186291/169011

13. Maturana H. Emoções e linguagem na educação e na política. $3^{\text {a }}$ ed. Belo Horizonte (MG): Editora UFMG; 2002.

14. Haddad JGV, Zoboli ELCP. O Sistema Único de Saúde e o giro ético necessário na formação do enfermeiro. O Mundo da Saúde [internet]. 2010 [cited 2014 Oct 28]; 34(1). Available from: http:/ / www.saocamilo-sp. br/pdf/mundo_saude/74/11_Sistema\%20Unico $\% 20$ de\%20Saude.pdf

15. Oliveira BRG, Viera CS, Collet N, Lima RAG. Acesso de primeiro contato na atenção primária em saúde para crianças. Rev RENE [internet]. 2012 [cited 2014 Oct 28]; 13(2). Available from: http://www. revistarene.ufc.br/revista/index.php/revista/ article/view/217

16. Morin E. Educação e complexidade: os sete saberes e outros ensaios. $6^{\text {a }}$ ed. São Paulo (SP): Cortez; 2013. 